\title{
Pro- and anti-inflammatory macrophages express a sub-type specific purinergic receptor profile
}

\author{
J. Merz ${ }^{1}$ - A. Nettesheim ${ }^{1}$ - S. von Garlen ${ }^{1}$ - P. Albrecht ${ }^{1}$ - B. S. Saller ${ }^{2,3} \cdot$ J. Engelmann $^{1} \cdot$ L. Hertle $^{1} \cdot$ I. Schäfer $^{1}$. \\ D. Dimanski ${ }^{1}$ - S. König ${ }^{1}$ - L. Karnbrock ${ }^{1} \cdot K_{\text {. Bulatova }}{ }^{1}$ - A. Peikert ${ }^{1} \cdot$ N. Hoppe ${ }^{1}$ - I. Hilgendorf ${ }^{1}$ - C. von zur Mühlen ${ }^{1}$. \\ D. Wolf ${ }^{1} \cdot$ O. Groß $ß^{2,3,4,5} \cdot$ C. Bode ${ }^{1} \cdot$ A. Zirlik ${ }^{6} \cdot$ P. Stachon ${ }^{1}$ (I)
}

Received: 3 August 2020 / Accepted: 7 June 2021 / Published online: 20 July 2021

(C) The Author(s) 2021

\begin{abstract}
Extracellular nucleotides act as danger signals that orchestrate inflammation by purinergic receptor activation. The expression pattern of different purinergic receptors may correlate with a pro- or anti-inflammatory phenotype. Macrophages function as pro-inflammatory M1 macrophages (M1) or anti-inflammatory M2 macrophages (M2). The present study found that murine bone marrow-derived macrophages express a unique purinergic receptor profile during in vitro polarization. As assessed by real-time polymerase chain reaction (PCR), G $\alpha$ s-coupled $\mathrm{P} 1$ receptors $\mathrm{A} 2 \mathrm{~A}$ and $\mathrm{A} 2 \mathrm{~B}$ are upregulated in $\mathrm{M} 1$ and $\mathrm{M} 2$ compared to M0, but A2A 15 times higher in $\mathrm{M} 1$. The ionotropic $\mathrm{P} 2$ receptor $\mathrm{P} 2 \mathrm{X}_{5}$ is selectively upregulated in $\mathrm{M} 1$ - and $\mathrm{M} 2$-polarized macrophages. $\mathrm{P} 2 \mathrm{X}_{7}$ is temporarily expressed in M1 macrophages. Metabotropic P2Y receptors showed a distinct expression profile in M1 and M2-polarized macrophages: G $\alpha \mathrm{q}$ coupled $\mathrm{P} 2 \mathrm{Y}_{1}$ and $\mathrm{P} 2 \mathrm{Y}_{6}$ are exclusively upregulated in $\mathrm{M} 2$, whereas $\mathrm{G} \alpha \mathrm{i} 2 \mathrm{Y}_{13}$ and $\mathrm{P} 2 \mathrm{Y}_{14}$ are overexpressed in M1. This consequently leads to functional differences between M1 and M2 in response to adenosine di-phosphate stimulation (ADP): In contrast to M1, M2 showed increased cytoplasmatic calcium after ADP stimulation. In the present study we show that bone marrow-derived macrophages express a unique repertoire of purinergic receptors. We show for the first time that the repertoire of purinergic receptors is highly flexible and quickly adapts upon pro- and anti-inflammatory macrophage differentiation with functional consequences to nucleotide stimulation.
\end{abstract}

Keywords Macrophages · Polarization · Purinergic receptor: Inflammation

Julian Merz graduated in biology and molecular medicine with a MSc from the University of Freiburg in 2016 and started his MD training in 2017. He completed his $\mathrm{PhD}$ in the topic of danger signals and cardiovascular immunology in 2020. Since 2019 he is the deputy head of the research group "danger signals in cardiovascular diseases" at the University Hospital of Freiburg. His research investigates the role of danger signals, such as extracellular nucleotides and inflammasome particles, during the pathogenesis of metabolic syndrome and cardiovascular diseases in murine disease models as well as patient samples. In May 2023 he will complete his MD training and start his residency training in Internal Medicine. In the future Julian Merz aims to translate his research approaches to the "bed-side" and thereby bridging basic research and clinical relevance as a prospective clinician scientist.

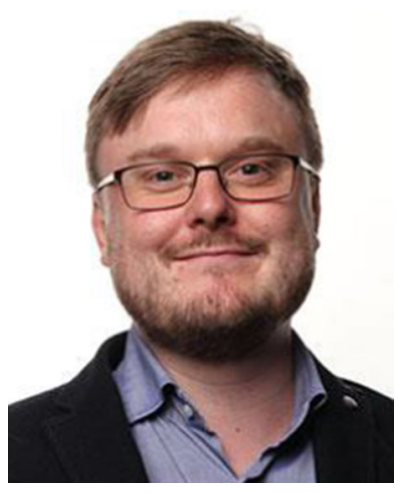

\section{P. Stachon}

peter.stachon@universitaets-herzzentrum.de

1 Department of Cardiology and Angiology I, Heart Center Freiburg University, Faculty of Medicine, University of Freiburg, Hugstetter Str. 55, 79106 Freiburg, Germany

2 Institute of Neuropathology, Medical Center - University of Freiburg, Faculty of Medicine, University of Freiburg,

79106 Freiburg, Germany
3 Faculty of Biology, University of Freiburg, 79104 Freiburg, Germany

4 Signalling Research Centres BIOSS and CIBSS, University of Freiburg, 79104 Freiburg, Germany

5 Center for Basics in NeuroModulation (NeuroModulBasics), Faculty of Medicine, University of Freiburg, 79106 Freiburg, Germany

6 Department of Cardiology, University Hospital Graz, Graz, Austria 


\section{Introduction}

Macrophages play a fundamental role in many immunological processes and orchestrate inflammation in many diseases [1]. Their immunological impact is highly flexible and dependent on environmental stimuli of the current surrounding. According to their immunological function, macrophages can be divided into a pro-inflammatory M1 and an antiinflammatory M2 subtype. In this context, pro-inflammatory stimuli like interferon (IFN $\gamma$ ) and lipopolysaccharide (LPS) promote the M1, whereas stimuli like interleukin-4 (IL-4) promote the anti-inflammatory M2 polarization [2]. A detailed characterization of this polarization spectrum is challenging and valid surface markers for M1 and M2 differentiation remain to be discovered [3].

Several stimuli within the extracellular matrix promote macrophages towards an anti- or pro-inflammatory phenotype. One important pro-inflammatory factor is extracellular nucleotides and their recognition by purinergic receptors. Dying cells release nucleotides into the extracellular environment where they act as so-called damage-associated molecular patterns (DAMPs). There, nucleotide triphosphates such as ATP and UTP can be de-phosphorylated by the ectonucleotidase CD39 to nucleotide diphosphates like ADP and UDP as well as inert nucleotide monophosphates such as AMP and UMP. The ectonucleotidase CD73 converts nucleoside monophosphates (AMP and UMP) to nucleosides such as adenosine and the inert uridine. Thus, ectonucleotidase-dependent degradation shapes the composition of extracellular nucleotides. This extracellular nucleotide and nucleoside composition orchestrates immunological processes via the activation of purinergic receptors. Purinergic receptors can be divided into adenosine recognizing P1 receptors and nucleotide recognizing P2 receptors. Gprotein coupled $\mathrm{P} 1$ receptors have rather anti-inflammatory effects, whereas metabotropic G-protein coupled P2Y and ionotropic ATP-dependent $\mathrm{P} 2 \mathrm{X}$ receptors are rather pro-inflammatory. P1 receptors are further sub-divided into high sensitivity $\mathrm{G} \alpha \mathrm{i}(\mathrm{A} 1)$ and $\mathrm{G} \alpha \mathrm{s}(\mathrm{A} 2 \mathrm{~A})$ as well as low sensitivity $\mathrm{G} \alpha \mathrm{i}$ (A3) and G $\alpha$ s (A2B) receptors. Murine nucleotide P2Y receptors can be divided into the G $\alpha$ q-coupled ADP-dependent P2 $\mathrm{Y}_{1}$, ATP-dependent P2 $\mathrm{Y}_{2}$, ATP/UTP-dependent $\mathrm{P} 2 \mathrm{Y}_{4}$, and UDP-dependent $\mathrm{P}_{2} \mathrm{Y}_{6}$ as well as the G $\alpha$ s-coupled ADP-dependent $\mathrm{P} 2 \mathrm{Y}_{12}, \mathrm{P}_{2} \mathrm{Y}_{13}$ and UDP-glucose-dependent $\mathrm{P} 2 \mathrm{Y}_{14}$ receptor. The ionotropic $\mathrm{P} 2 \mathrm{X}$ receptors $\mathrm{P} 2 \mathrm{X}_{1-7}$ are all activated by ATP and differ in open-time, ion-flux, and ATP sensitivity with $\mathrm{P} 2 \mathrm{X}_{7}$ building up the biggest pore, the most pronounced ionflux and lowest sensitivity to extracellular ATP [4]. It is known that certain cell types like neutrophils express a unique profile of purinergic receptors [5]. This unique receptor profile integrates into a specified reaction to extracellular nucleotides/nucleosides. For instance, activation of the formyl-peptide receptor by pathogen-derived formylated peptides promotes the release of ATP and thereby activates adjacent $\mathrm{P}_{2} \mathrm{Y}_{2}$ receptors.
This pathogen-directed signal leads to the translocation of A3 receptors to the side of $\mathrm{P}_{2} \mathrm{Y}_{2}$ activation. Membrane-bound ectonucleotidases hydrolyze ATP and produce an apicolateral adenosine gradient activating the translocated $\mathrm{A} 3$ receptor. This apical A3/P2 $\mathrm{Y}_{2}$ composition promotes chemotaxis of neutrophils towards an formylated peptide-driven ATP gradient [5]. Accordingly, the expression of a certain purinergic receptor profile further enhances the complexity of extracellular nucleotide/nucleoside signaling and shapes environmental stimuli.

The purinergic receptor profile uniquely defines the cellular behavior to nucleotides and nucleosides in the extracellular environment. In this work we aim to analyze the purinergic receptor profile of pro-inflammatory and anti-inflammatory macrophages. We further want to access if this profile correlates with molecular behaviors in these macrophage subtypes and possibly serve as potential new M1/M2 marker.

\section{Materials und methods}

\section{Macrophage cultivation and differentiation}

C57B16/J mice were euthanized using $\mathrm{CO}_{2}$. Both femurs were collected; the diaphysis removed and rinsed though a 40- $\mu \mathrm{m}$ cell strainer (Falcon) with ice-cold PBS w/o calcium and magnesium (Lonza). These bone marrow cells were centrifuged with $300 \mathrm{~g}$ for $5 \mathrm{~min}$ at $4^{\circ} \mathrm{C}$, re-suspended in macrophage differentiation medium containing 500ml DMEM (Gibco), 10\% FCS (PAN Biotech), 1\% penicillin-streptomycin (P/S) (Bio Whittaker), and 30ng/ml M-CSF (PeproTech) and plated in an incubator at $37^{\circ} \mathrm{C}$ and $5 \% \mathrm{CO}_{2}$. Non-adherent cells were removed after 3 days by replacing the macrophage differentiation medium. The macrophage differentiation medium was removed after 7 days, and adherent cells were washed twice with PBS with calcium and magnesium (Lonza). Macrophage differentiation and cell culture purity was verified via flow cytometric analysis. For M1 differentiation, BMDMs were incubated $5 \mathrm{~h}$ at $37^{\circ} \mathrm{C}$ and $5 \% \mathrm{CO}_{2}$ with DMEM $+10 \% \mathrm{FCS}$ $+1 \% \mathrm{P} / \mathrm{S}$ with $10 \mathrm{ng} / \mathrm{ml}$ IFN $\gamma$ (PeproTech) and $100 \mathrm{ng} / \mathrm{ml}$ LPS from Escherichia coli 055:B5 (Sigma Aldrich). For M2 differentiation, BMDMs were incubated $5 \mathrm{~h}$ at $37^{\circ} \mathrm{C}$ and $5 \% \mathrm{CO}_{2}$ with DMEM $+10 \%$ FCS $+1 \%$ P/S with $20 \mathrm{ng} / \mathrm{ml} \mathrm{IL-4}$ (PeproTech). Non-stimulated M0 macrophages only received $\mathrm{DMEM}+10 \% \mathrm{FCS}+1 \% \mathrm{P} / \mathrm{S}$ for $5 \mathrm{~h}$ at $37^{\circ} \mathrm{C}$ and $5 \% \mathrm{CO}_{2}$.

\section{Flow cytometry}

Bone marrow cells incubated for 7 days with macrophage differentiation medium were rinsed twice with PBS w/o calcium and magnesium (Lonza). BMDMs were detached using $5 \mathrm{mM}$ EDTA (AppliChem) in PBS w/o calcium and magnesium. 
Detached cells were centrifuged at $300 \mathrm{~g}$ for $5 \mathrm{~min}$ and resuspended in FACS buffer (PBS w/o calcium and magnesium $+1 \%$ FCS $+0.5 \%$ BSA (AppliChem)). Lineage staining was introduced by adding CD3e (clone: 145-2C11, eBioscience), CD19 (clone: eBio1D3, eBioscience), NK1.1 (clone: PK136, $\mathrm{BD}$ ), and Ly6G (clone: 1A8, BD) in PE. To characterize leukocytes, we used CD45.2 (clone: 104, eBioscience) in eFluor 450; for myeloid cells, we used CD11b (clone: M1/70, BD) in APC-Cy7; and for macrophage specific identification, we used F4/80 (clone: BM8, Biolegend) in PE-Cy7. For purinergic receptor staining, we used $\mathrm{P}_{2} \mathrm{Y}_{1}$ (clone: E-1, Santa Cruz) and $\mathrm{P}^{2} \mathrm{X}_{7}$ (clone: 1F11, Biolegend). As appropriate isotype controls, we used mouse IgG2a (Biolegend), mouse IgG1 (BD), and rat $\operatorname{IgG} 2 \mathrm{~b}$ (Thermo Fisher). Stained cells were analyzed using a BD FACSCanto II flow cytometer.

\section{RNA isolation and CDNA transcription}

RNA isolation was performed with the RNeasy Mini Kit from Qiagen according to manufacturers' protocol with the optional DNase step. The obtained RNA quantity and purity was accessed via NanoDrop (Thermo Scientific) and diluted to a final concentration of $100 \mathrm{ng} / \mu \mathrm{l}$ for prior cDNA transcription. The transcription into cDNA was performed with the high-capacity cDNA reverse transcription kit (Applied Biosystems) according to manufacturers' protocol using $1 \mu \mathrm{g}$ of the isolated RNA.

\section{Real-time PCR}

Real-time PCR was performed in a 96-well white-colored RTPCR plate (Bio-Rad), using 10 $\mu$ l ORA 2x TaqMan Master Mix (highQu), $1 \mu$ l of the target gene primer (Thermo Fisher), $7 \mu 1$ of nuclease-free water, $1 \mu l$ of housekeeping gene primer ( $\beta$-Actin), and $1 \mu \mathrm{l}$ of cDNA per reaction. PCR reaction was performed and data was acquired in a CFX96 touch real-time PCR detection system (Bio-Rad). Following primers from Thermo Fisher (FAM-coupled) were used in this manuscript: Arg1 (Mm00475988_m 1), TGF $\beta$ (Mm01178820_m1), IRF4 (Mm00516431_m1), IL-1 $\beta$ (Mm01336189_m1), TNF $\alpha\left(\mathrm{Mm00443258 \_ m1),} \mathrm{NOS2}\right.$ (Mm00440502_m1), P2Y1 (Mm02619947_s1), P2Y2 (Mm01274120_m1), P2Y4 (Mm00445136_s1), P2Y6 (Mm01275472_m1), P2Y12 (Mm0195043_s1), P2Y13 (Mm01951265_s1), P2Y14 (Mm01952477_s1), A1 (Mm01308023_m1), A2A (Mm00802075_m1), A2B (Mm00839292_m1), A3 (Mm00802076_m1), CD39 (Mm00515447 m1), CD73 (Mm00501910 m1), P2X1 (Mm00435460_m1), P2X2 (Mm00462952_m1), P2X3 (Mm00523699_m1), P2X4 (Mm00501787_m1), P2X5 (Mm00473677_m1), P2X6 (Mm00440591_m1), and P2X7 (Mm01199500 m1). Expression levels below a threshold of $2^{\text {-dCT }}=4 * 10^{-5}$ was designated as very low or even questionably expressed (but with still quantifiable CT values above 31 ) and therefore designated as below threshold (b.t.). Genes with no quantifiable CT values (CT values above 38 ) were designated as not detectable (n.d.).

\section{Fluo-4 AM microscopy}

The procedure was performed according to the manufacturers' protocol (Molecular Probes). Briefly, Fluo-4 AM working solution was produced by vortexing $100 \mu \mathrm{l}$ of $100 \mathrm{x}$ power load with $10 \mu l$ of 1000x Fluo-4 AM (Molecular Probes) in a 15-ml Falcon. Afterwards, $10 \mathrm{ml}$ of life cell imaging (LCI) solution (Molecular Probes) containing $20 \mathrm{mM}$ glucose and $100 \mu \mathrm{l}$ of the aniontransport inhibitor 100x probenecid (Thermo Fisher) was added. Medium from BMDMs was removed and cells were washed once with LCI solution w/o glucose and probenecid. Cells were covered with $2 \mathrm{ml}$ Fluo-4 AM working solution and incubated for $30 \mathrm{~min}$ at $37^{\circ} \mathrm{C}$ and $5 \% \mathrm{CO}_{2}$. Afterwards, cells were washed once with LCI w/o glucose and probenecid. For fluorescence detection, the cells were covered with LCI with $20 \mathrm{mM}$ glucose. The cells were recorded under a fluorescence microscope in the FITC channel during stimulation with $200 \mu \mathrm{M}$ ADP (Sigma Aldrich). In order to quantify the fluorescence signal, we recorded different wells throughout the whole experiment. Fluorescence intensity mean values of marked spots were calculated by the Zen imaging software. For background suppression, we marked $n=4$ rectangular spots without any cells and measured the fluorescence intensity mean value of those spots at set timepoints during the entire experiment $(9,6$, and $3 \mathrm{~s}$ before ADP administration; directly at the time-point of ADP administration; as well as 3, $6,9,12,15,18$, and $21 \mathrm{~s}$ after ADP administration). Additionally, in order to quantify the fluorescence signal, $\mathrm{n}=20$ rectangular spots containing cells (we made sure that the whole cell fit into the frame) were marked. In accordance with the background suppression spots, the fluorescence intensity mean values of those spots were calculated for the same timepoints set for the background suppression spots in dependence of the ADP administration time-point. The average of the fluorescence intensity mean values of the background suppression spots were subtracted from the corresponding fluorescence intensity mean values of the spots containing cells. The relative fluorescence intensity represents the relative increase of the background corrected fluorescence intensity mean value in relation to its corresponding background corrected fluorescence intensity mean value $9 \mathrm{~s}$ before ADP administration gives the relative fluorescence intensity.

\section{Caspase- 1 assay}

Caspase-1 activity was accessed using the caspase-1 Glo kit from Promega. All experiments and data acquisition were performed according to the manufacturers protocol. Inflammasome activation experiments were performed as described previously [6]. Briefly, to prime the inflammasome, 
BMDMs were incubated for different durations with DMEM $+10 \% \mathrm{FCS}+1 \% \mathrm{P} / \mathrm{S}$ containing $100 \mathrm{ng} / \mathrm{ml}$ LPS from $E$. coli 055:B5 (Sigma Aldrich). Assembly was achieved by subsequently adding 5mM ATP (Sigma Aldrich) to the BMDMs.

\section{Western blot}

For immunoblot analysis of total cell lysates, cells were washed with PBS and lysed in SDS- and DTT-containing sample buffer. Proteins were separated by SDS-PAGE and transferred to nitrocellulose membranes using standard techniques [7]. Primary antibodies were as follows: anti-P2X7 (clone: EPR24130-77, Abcam), anti-P2Y1 receptor (APR-009, Alomone Labs), and anti-A1 (clone: HA1, Santa Cruz).

\section{Statistics}

The statistical analysis was performed with GraphPad Prism. The expression and fold change of the examined genes were analyzed using an unpaired two-tailed $t$-test. For the statistical analysis of the relative fluorescence intensity, a two-tailed paired $t$-test was performed.

\section{Results}

\section{Bone marrow-derived macrophages express a unique purinergic receptor profile}

In order to investigate the expression profile of purinergic receptors in macrophages, we cultivated bone marrow cells from C57B16/J mice. Flow cytometric analysis of the predifferentiated, directly isolated bone marrow cell culture revealed a heterogeneous cell suspension consisting of leukocytes $\left(\mathrm{CD} 45^{+}\right)$, non-leukocytes $\left(\mathrm{CD} 45^{-}\right)$, myeloid $\left(\mathrm{CD} 11 \mathrm{~b}^{+}, \mathrm{lin}^{-}\right)$as well as other immune cells $\left(\operatorname{lin}^{+}\right)$with only few $\mathrm{CD}^{+} 5^{+}, \mathrm{CD}_{11} \mathrm{~b}^{+}$, lin', and $\mathrm{F} 4 / 80^{+}$macrophages (Fig. 1a). Differentiation of this cell culture via M-CSF resulted in a pure $\mathrm{CD} 45.2^{+}, \mathrm{CD}_{11 \mathrm{~b}^{+}}$, lin', and $\mathrm{F} 4 / 80^{+}$macrophage cell culture (Fig. 1b). Expressional analysis of macrophages $\left(\mathrm{CD} 45^{+}, \mathrm{lin}^{-}, \mathrm{CD} 11 \mathrm{~b}^{+}, \mathrm{F} 4 / 80^{+}\right)$revealed a distinct purinergic receptor profile (Fig. 1c). We identified high expression of the purinergic receptors $\mathrm{P}_{2} \mathrm{Y}_{2}, \mathrm{P}_{2} \mathrm{Y}_{6}$, $\mathrm{P} 2 \mathrm{X}_{4}$, and $\mathrm{P} 2 \mathrm{X}_{7}$. The $\mathrm{P} 1$ receptor $\mathrm{A} 2 \mathrm{~B}$ and $\mathrm{P} 2 \mathrm{Y}_{14}$ showed intermediate expression levels, whereas the $\mathrm{P} 1$ receptor $\mathrm{A} 2 \mathrm{~A}$ and $\mathrm{P}_{2} \mathrm{Y}_{1}$ revealed low expression levels. The ectonucleotidase CD39 was highly expressed, while the ectonucleotidase CD73 showed a low expression. We defined expression levels below a threshold of $4 * 10^{-5}$ for the $2^{-\mathrm{dCT}}$ value as very low. This threshold equals a $14.61 \mathrm{dCT}$ value between housekeeping gene and target gene. The CT value of the $\beta$-actin housekeeping gene in our experiments was $17.71 \pm 1.42$ ( $\mathrm{SD}, \mathrm{n}=841)$. Accordingly, we refer target genes with more than 30.9 CT values as below threshold (b.t.) in the following results.

\section{M1/M2 polarization leads to upregulation of Gas- coupled P1 receptors, with high expression of the high-sensitivity A2A receptor on M1 macrophages}

Macrophages can be differentiated into pro-inflammatory M1 and anti-inflammatory M2 macrophage subtypes according to either pro- or anti-inflammatory stimuli [3]. To investigate if these states of differentiation alter the expression of purinergic receptors, we cultivated macrophages and stimulated these with either IFN $\gamma$ and LPS to promote M1differentiation or IL-4 to promote M2-differentiation. The efficacy of differentiation was analyzed via the established M2 markers arginase-1 (Arg1), transforming growth factor beta (TGF $\beta$ ), and interferon regulatory factor 4 (Irf4) as well as the M1 markers IL-1 $\beta$, tumor necrosis factor $\alpha(\mathrm{TNF} \alpha)$, and nitric oxide synthase 2 (Nos2) (Fig. 2a). Stimulation with IL-4 leads to the upregulation of the M2 specific markers Arg1, TGF $\beta$, and IRF4 as well as the downregulation of the pro-inflammatory M1 markers IL- $1 \beta$ and TNF $\alpha$. Stimulation with IFN $\gamma$ and LPS leads to the downregulation of the M2 markers and promoted the upregulation of the M1specific markers IL- $1 \beta, T N F \alpha$, and NOS2. In the next step, we analyzed the $\mathrm{P} 1$ and ectonucleotidase expression in those differentiated M1 and M2 macrophages compared to unstimulated M0 macrophages. Both M1 and M2 differentiation correlated with an upregulation of the G $\alpha$ s-coupled P1 receptors A2A and A2B (Fig. 2b). In this context, the highsensitivity adenosine receptor A2A showed a 15 -times higher expression in M1 macrophages compared to M2 macrophages. The expression levels of the low-sensitivity adenosine receptor A2B showed no significant difference between M1 and M2 macrophages. Regarding the Gai-coupled P1 receptors, the high-sensitivity adenosine receptor A1 was not detectable (confirmed by western blot analysis; data not shown) and the low-sensitivity adenosine receptor A3 was below threshold in all macrophage subtypes. Both M1 and M2 differentiation lead to the downregulation of the ectonucleotidase CD39. Nevertheless, M2 macrophages still showed a higher CD39 expression compared to M1 macrophages. The expression of the ectonucleotidase CD73 was below threshold after M1 and M2 polarization.

\section{M1 polarization leads to the downregulation of the inflammasome regulator $\mathrm{P}_{2} \mathrm{X}_{7}$ which prevents caspase-1 activation in macrophages after prolonged pro-inflammatory stimulation}

Naïve M0 macrophages only express the ATP dependent ionotropic receptors $\mathrm{P} 2 \mathrm{X}_{4}$ and $\mathrm{P} 2 \mathrm{X}_{7}$. Both $\mathrm{M} 1$ and $\mathrm{M} 2$ 


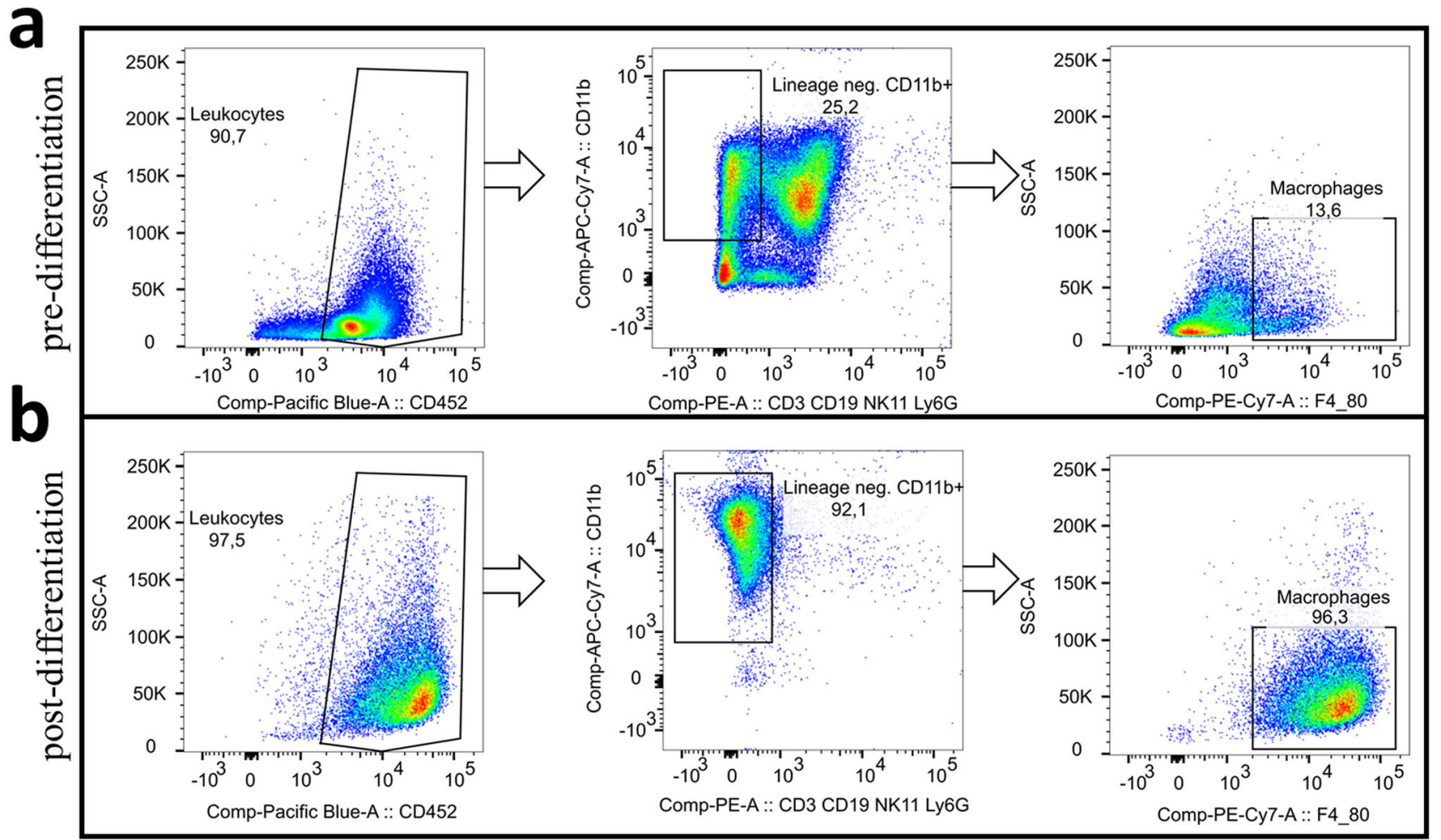

C

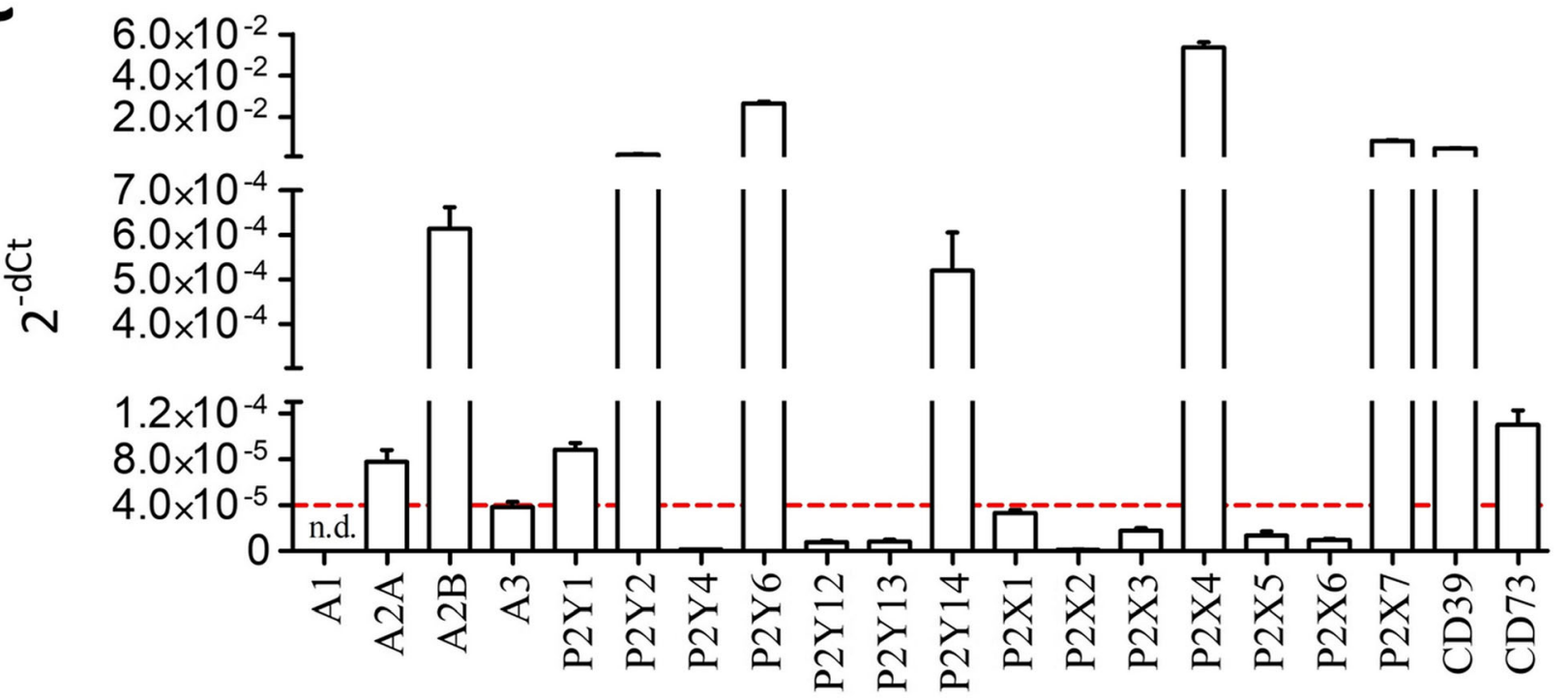

Fig. 1 Purinergic receptor expression in bone marrow-derived macrophages (BMDMs) from C57B16/J mice. Flow cytometric analysis of a directly isolated bone marrow and $\mathbf{b}$ differentiated 7 days with $30 \mathrm{ng} / \mathrm{ml}$ M-CSF. Lineage describes a combination of antibodies recognizing CD3, CD19, Ly6G, and NK1.1, respectively. Macrophages are characterized as

differentiation lead to the upregulation of $\mathrm{P} 2 \mathrm{X}_{5}$ receptor (Fig. 3a). However, M1 polarization caused a downregulation of $\mathrm{P} 2 \mathrm{X}_{4}$ and $\mathrm{P} 2 \mathrm{X}_{7}$. Given the pivotal role of $\mathrm{P} 2 \mathrm{X}_{7}$ during inflammation via an assembly of the inflammasome [6], it seemed unlikely that this receptor was downregulated in the pro-
$\mathrm{CD} 5^{+}, \mathrm{CD} 11 \mathrm{~b}^{+}$, and $\mathrm{F} 4 / 80^{+}$and lineage negative population. $\mathbf{c}$ Realtime PCR purinergic receptor and ectonucleotidase expression profile of unstimulated BMDMs described as $2^{-\mathrm{dCt}}$ values. Red dotted lines visualize the threshold of very low expressional levels. n.d., not detectable

inflammatory M1 subtype. To investigate a potential early upregulation of $\mathrm{P}_{2} \mathrm{X}_{7}$ during $\mathrm{M} 1$ differentiation, its expression was analyzed at early timepoints (Fig. 3b). Nevertheless, $\mathrm{P}_{2} \mathrm{X}_{7}$ expression declined over the whole M1 differentiation period. To further analyze this expressional downregulation of 
Fig. 2 Expression of specific M1/ M2 markers upon pro- and antiinflammatory differentiation as well as P1 and ectonucleotidases in unstimulated M0 compared to differentiated M1 and M2 macrophages. a Real-time PCR detection described as ddCt fold increase of specific M1/M2 markers in BMDMs stimulated for $5 \mathrm{~h}$ with $10 \mathrm{ng} / \mathrm{ml} \mathrm{IFN} \gamma+100 \mathrm{ng} / \mathrm{ml}$ LPS (red, striped bars) for M1 differentiation and $5 \mathrm{~h}$ with 20ng/ml IL-4 (green bars) for M2 differentiation. BMDMs which only received medium for $5 \mathrm{~h}$ (white bars) are described as M0 macrophages and serve as reference value for the ddCt fold increase comparison. b Real-time PCR expression described as $\mathrm{ddCt}$ fold increase referred to M0 expression (white bars) compared to M1 (red, striped bars)- and M2 (green bars)-differentiated macrophages. n.d., not detectable; b.t., below threshold; * $\mathrm{p}<0.05, * * \mathrm{p}$ $<0.01, * * * \mathrm{p}<0.001$

\section{a}

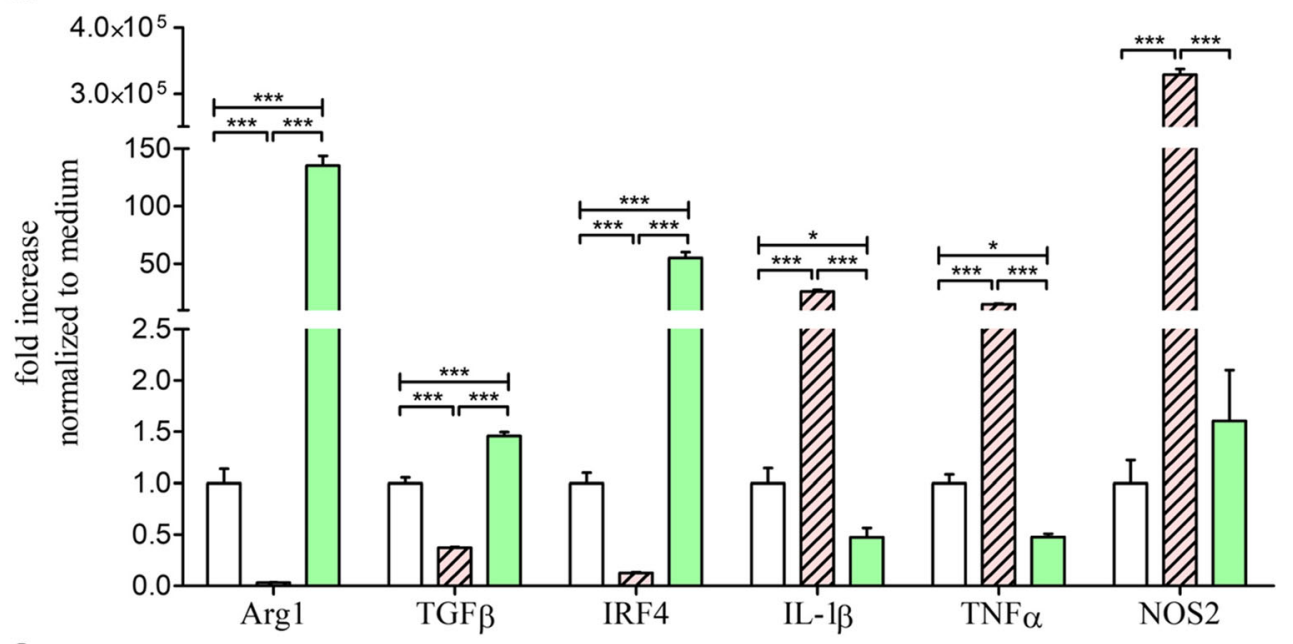

b

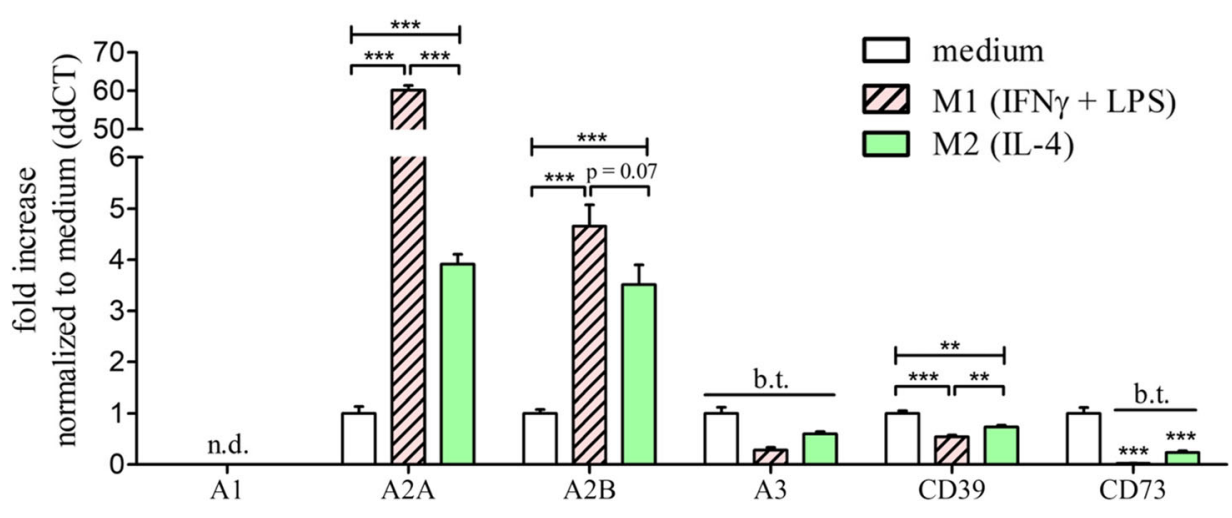

$\mathrm{P} 2 \mathrm{X}_{7}$ on the protein levels, flow cytometric (Fig. 3c-f) and western blot analysis were performed (Fig. 3g-h). Via flow cytometric analysis, BMDMs can be separated into a $\mathrm{P} 2 \mathrm{X}_{7}$ positive and a $\mathrm{P} 2 \mathrm{X}_{7}$ negative population. Intriguingly, the $\mathrm{P}_{2} \mathrm{X}_{7}$ negative population is more pronounced in M1-primed macrophages (Fig. 3d) compared to M0- (Fig. 3c) and M2primed (Fig. 3e) macrophages. In accordance to the increasing $\mathrm{P}_{2} \mathrm{X}_{7}$ negative population in $\mathrm{M} 1$, the proportion of the $\mathrm{P} 2 \mathrm{X}_{7}$ positive BMDM population declines over time in the M1primed culture compared to M0- and M2-primed cultures (Fig. 3f). This decline of the $\mathrm{P} 2 \mathrm{X}_{7}$ positive population was also measurable in a western blot analysis of P2X $\mathrm{X}_{7}$ (Fig. $3 \mathrm{~g}$ and $\mathrm{h}$ ). To assess if the expression translates into a functional outcome, the inflammasome assembly capacity of M1 macrophages over time was analyzed (Fig. 3i). Whereas short-term M1 differentiation via the pro-inflammatory LPS stimulus followed by ATP administration leads to an increased caspase-1 activity, prolonged pro-inflammatory M1 differentiation completely prevented caspase-1 activation upon ATP administration.

\section{M1 polarization upregulates Gai, whereas M2 polarization upregulates Gaq-coupled purinergic receptors}

The metabotropic purinergic receptors can be divided into G $\alpha$ q-coupled P2 $Y_{1}, P 2 Y_{2}, P 2 Y_{4}$, and $\mathrm{P} 2 Y_{6}$ and $\mathrm{G} \alpha \mathrm{i}-$ coupled $\mathrm{P} 2 \mathrm{Y}_{12}, \mathrm{P} 2 \mathrm{Y}_{13}$, and $\mathrm{P} 2 \mathrm{Y}_{14}$ receptors, respectively. Whereas M2 polarization leads to the upregulation of the G $\alpha$ q-coupled ADP receptor P2 $Y_{1}$ and the UDP receptor $\mathrm{P}_{2} \mathrm{Y}_{6}$, pro-inflammatory $\mathrm{M} 1$ differentiation promoted the

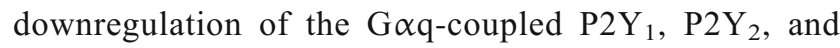
$\mathrm{P}^{2} \mathrm{Y}_{6}$ receptors (Fig 4a). Intriguingly, the expression levels of $\mathrm{P}_{2} \mathrm{Y}_{1}$ decreased below threshold levels in M1 macrophages. The expression levels of the ATP/UTP receptor $\mathrm{P}_{2} \mathrm{Y}_{4}$ was below threshold in all three macrophage subtypes. However, M1 polarization was accompanied with an upregulation of the G $\alpha$ i-coupled ADP receptor $\mathrm{P}_{2} \mathrm{Y}_{13}$ and the UDP-glucose receptor $\mathrm{P}_{2} \mathrm{Y}_{14}$ (Fig. 4b). Of note, $\mathrm{P}_{2} \mathrm{Y}_{13}$ was below the detection threshold in both M0 and M2 macrophages, and thereby uniquely expressed 

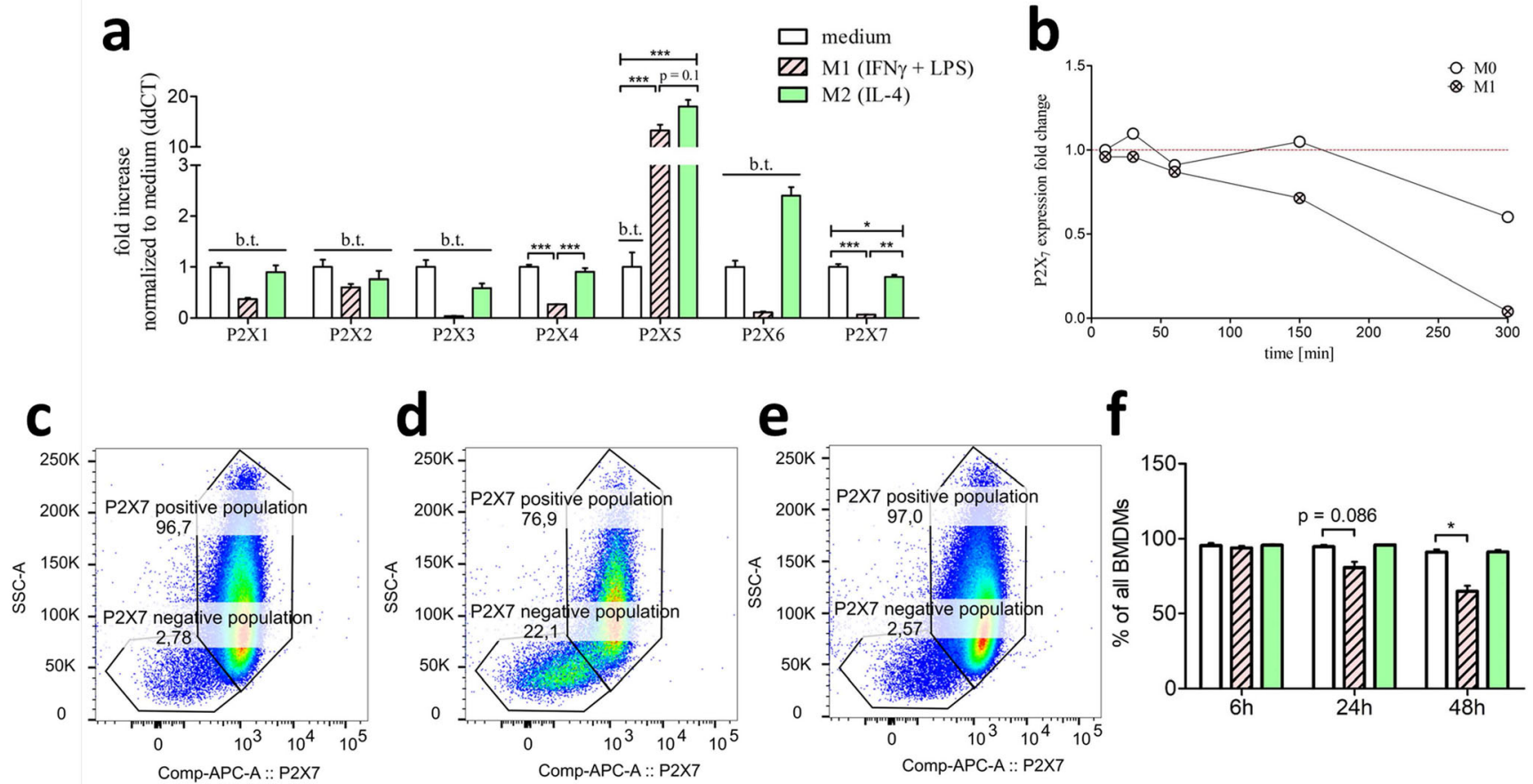

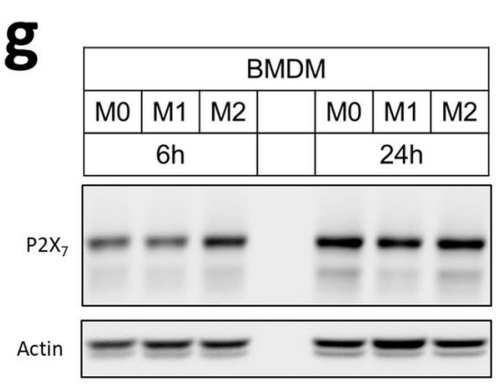

h

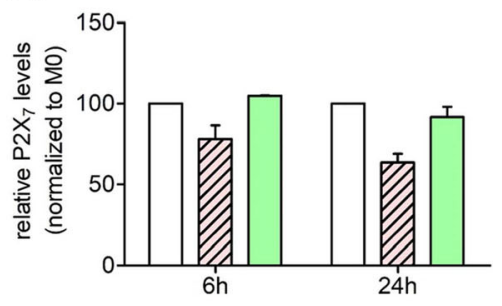

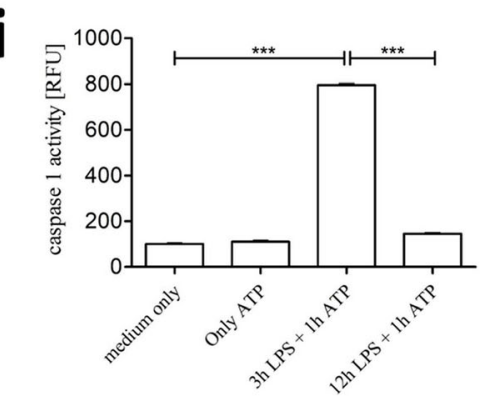

Fig. 3 Ionotropic P2X expression in M1-/M2-differentiated macrophages compared to unstimulated M0 macrophages and the impact on inflammasome activation. BMDMs stimulated for $5 \mathrm{~h}$ with $10 \mathrm{ng} / \mathrm{ml} \mathrm{IFN} \gamma+100 \mathrm{ng} / \mathrm{ml}$ LPS are described as M1 macrophages (red, striped bars) and BMDMs simulated for $5 \mathrm{~h}$ with $20 \mathrm{ng} / \mathrm{ml} \mathrm{IL-4}$ are described as M2 macrophages (green bars). BMDMs which only received medium for $5 \mathrm{~h}$ (white bars) are described as M0 macrophages. a Realtime PCR expression of P2X purinergic receptors in M1-/M2-differentiated macrophages described as ddCt fold increase referred to $\mathrm{M} 0$ expression levels. b $\mathrm{P}_{2} \mathrm{X}_{7} \mathrm{ddCt}$ fold change expression levels over time

in the pro-inflammatory M1 subtype. The expression of the Gai-coupled ADP receptor $\mathrm{P}_{2} \mathrm{Y}_{12}$ was below the threshold in all three macrophage activation states. According to the expressional analysis, M2 macrophages could uniquely respond to ADP via activation of the G $\alpha \mathrm{q}$ coupled $\mathrm{P}_{2} \mathrm{Y}_{1}$ receptor. Due to this, we aimed to evaluate the $\mathrm{P}_{2} \mathrm{Y}_{1}$ protein levels in $\mathrm{M} 0, \mathrm{M} 1$, and $\mathrm{M} 2$ macrophages using flow cytometric analysis (Fig. 4c-g). Incubation with IL-4 leads to the upregulation of cell surface P2Y on M2-differentiated macrophages compared to M0- or M1-differentiated macrophages (Fig. $4 \mathrm{c}$ and d). In direct comparison, the $\mathrm{P}_{2} \mathrm{Y}_{1}$-dependent mean-fluorescence compared to $\mathrm{P} 2 \mathrm{X}_{7}$ expression at time-point $\mathrm{t}=0 \mathrm{~min}$ in $\mathrm{M} 0$ macrophages. c-e representative flow cytometry dot-blots of $48 \mathrm{~h}$ stimulated $\mathbf{c} \mathrm{M} 0, \mathbf{d}$ $\mathrm{M} 1$, and e M2 macrophages. $\mathbf{f}$ Quantification of the $\mathrm{P} 2 \mathrm{X}_{7}$-positive population in percentage of all BMDMs. $\mathrm{g}$ Western blot analysis of $6 \mathrm{~h}$ and 24h differentiated M0, M1, and M2 macrophages with h normalized quantification to $\beta$-actin and in relation to M0 macrophages. $\mathbf{i}$ Inflammasome activation measured by caspase-1 Glo assay in shorttime (3h) and long-time (12h) 100ng/ml LPS primed macrophages and subsequent $5 \mathrm{mM}$ ATP stimulation. b.t., below threshold; * $\mathrm{p}<0.05$, ** $\mathrm{p}$ $<0.01, * * * \mathrm{p}<0.001$

intensity allows the distinction of a $\mathrm{P}_{2} \mathrm{Y}_{1}$-negative population of M1-differentiated macrophages from a $\mathrm{P} 2 \mathrm{Y}_{1}$ positive population of M2-differentiated macrophages (Fig. 4e-g).

\section{ADP promotes Gaq signaling in M2-polarized macro- phages due to a unique purinergic receptor profile}

In order to investigate the functional relevance of the altered expression and protein levels of $\mathrm{P}_{2} \mathrm{Y}_{1}, \mathrm{Ca}^{2+}$ flux upon ADP administration was measured in M2-polarized macrophages via Fluo-4 AM. Stimulation with ADP did not show any 
a

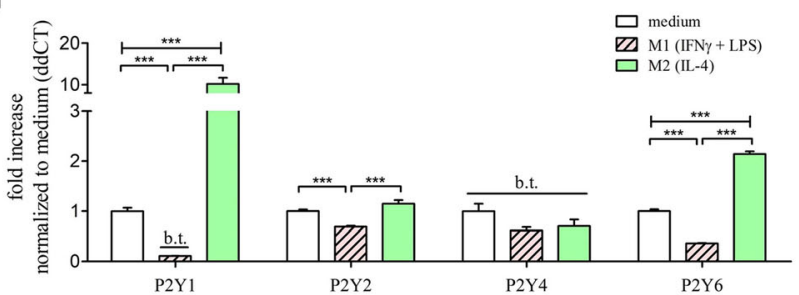

b

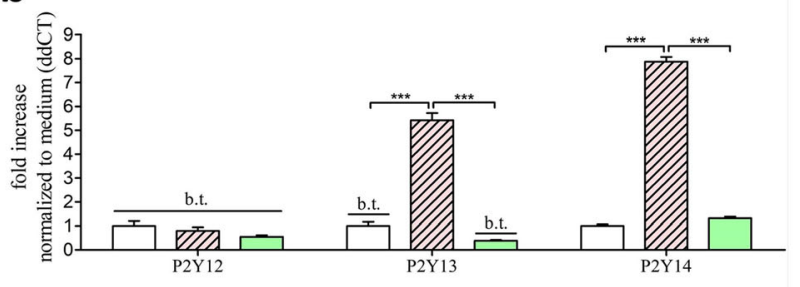

$f$

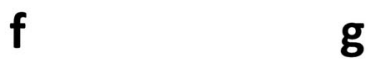

d e

e

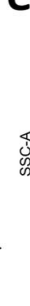

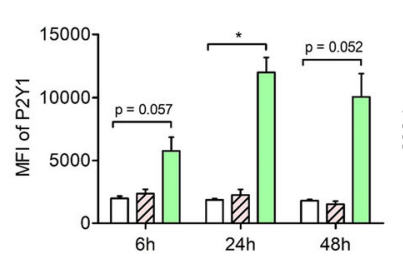

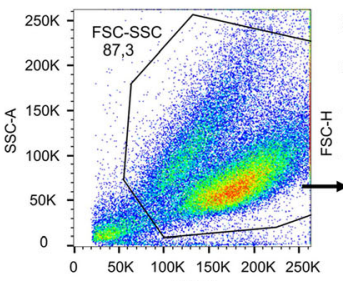

FSC-A

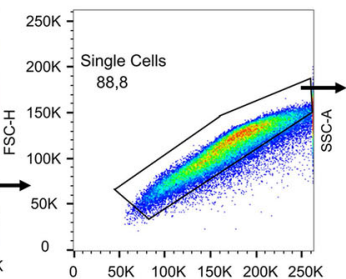

FSC-A g

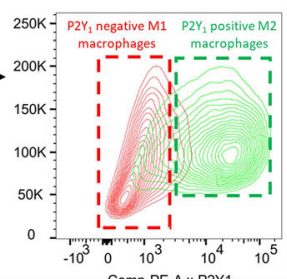

Comp-PE-A:: P2Y1
Fig. 4 Metabotropic P2Y expression in M1-/M2-differentiated macrophages compared to unstimulated M0 macrophages. BMDMs stimulated for $5 \mathrm{~h}$ with $10 \mathrm{ng} / \mathrm{ml} \mathrm{IFN} \gamma+100 \mathrm{ng} / \mathrm{ml} \mathrm{LPS}$ are described as M1 (red, striped bars) and BMDMs simulated for $5 \mathrm{~h}$ with $20 \mathrm{ng} / \mathrm{ml} \mathrm{IL}$ 4 are described as M2 macrophages (green bars). BMDMs which only received medium for $5 \mathrm{~h}$ (white bars) are described as M0 macrophages. a Real-time PCR expression of Gq-coupled P2Y purinergic receptors $\left(\mathrm{P}_{2} \mathrm{Y}_{1}, \mathrm{P}_{2} \mathrm{Y}_{2}, \mathrm{P}_{2} \mathrm{Y}_{4}\right.$, and $\mathrm{P} 2 \mathrm{Y}_{6}$ ) in M1-/M2-differentiated macrophages described as ddCt fold increase referred to $\mathrm{M} 0$ expression levels. b Realtime PCR expression of Gi-coupled P2Y purinergic receptors $\left(\mathrm{P} 2 \mathrm{Y}_{12}\right.$,

related increase of the $\mathrm{Ca}^{2+}$ dependent Fluo-4 AM fluorescence signal in M1-polarized macrophages (Fig. $5 \mathrm{a}$ and c). Nevertheless, upon ADP stimulation, M2-polarized macrophages responded with an increase of the $\mathrm{Ca}^{2+}$ dependent Fluo-4 AM fluorescence signal (Fig. 5 b and c).

\section{Discussion}

In an immunological context, adenosine $\mathrm{P} 1$ receptors and the nucleotide degrading ectonucleotidases CD39 and CD73 promote anti-inflammatory functions [8], whereas P2Y and P2X receptors orchestrate immunological processes in a rather proinflammatory context. For example, P2Y2 activation is accompanied with increased leukocyte infiltration during smokeinduced lung injury [9], peritonitis [10], atherosclerosis [11], and metabolic syndrome [12]. Depletion of the P2Y2 receptor reduces macrophage accumulation in visceral adipose tissue and ameliorates the outcome of metabolic syndrome in mice [12]. Furthermore, activation of the ionotropic P2X7 receptor leads to the assembly of inflammasome subunits in macrophages. The assembled inflammasome complex activates pro-caspase-1 by autocleavage process to fully functional caspase- 1 . Activated caspase-1 then proteolytically cleaves and thereby activates proinflammatory cytokines like IL-1 $\beta$. Depletion of P2X7 prevents
$\mathrm{P}_{2} \mathrm{Y}_{13}$, and $\mathrm{P} 2 \mathrm{Y}_{14}$ ) in M1-/M2-differentiated macrophages described as $\mathrm{ddCt}$ fold increase referred to $\mathrm{M} 0$ expression levels. c Flow cytometric P2 $\mathrm{Y}_{1}$-dependent histogram of $24 \mathrm{~h}$ differentiated M0 (black-lined), M1 (red-lined), and M2 (green-lined) macrophages. d Quantification of the $\mathrm{P}_{2} \mathrm{Y}_{1}$-dependent mean-fluorescence intensity of M0, M1, and M2 macrophages after differentiation timepoints $6 \mathrm{~h}, 24 \mathrm{~h}$, and $48 \mathrm{~h}$. e-g Gating strategy of $\mathrm{P} 2 \mathrm{Y}_{1}$-dependent M1 and M2 distinction. e Debry-exclusion gating via cell size (FSC) and granularity (SSC). f Single cell gating via FSC-A (area) and FSC-H (height). g M1 and M2 distinction via the cell surface antigen $\mathrm{P}_{2} \mathrm{Y}_{1}$. b.t., below threshold; $* * * \mathrm{p}<0.001$

inflammasome activation in lesional macrophages and improves atherosclerosis outcome in mice [13].

An abundance of immunological processes are regulated by the composition of extracellular nucleotides. Recognition of this nucleotide composition by numerous purinergic receptors further enhances the complexity of this system. In this context, the expression of a certain purinergic receptor repertoire critically defines the way a cell reacts to extracellular nucleotides. In this study, we show that bone marrowderived macrophages express a unique repertoire of purinergic receptors. Moreover, we show for the first time that this purinergic receptor repertoire is highly flexible and quickly adapts upon pro- and anti-inflammatory macrophage differentiation with functional consequences to nucleotide stimulation.

Unstimulated BMDMs express both the high-sensitivity (A2A) as well as the low-sensitivity (A2B) G $\alpha$ s-coupled adenosine $\mathrm{P} 1$ receptor. The expression levels of the G $\alpha \mathrm{i}$-coupled adenosine receptors $\mathrm{A} 1$ and $\mathrm{A} 3$ were either very low $(\mathrm{A} 3)$ or even not detectable (A1). These observations are in agreement with previous studies which detected $\mathrm{A} 2 \mathrm{~A}, \mathrm{~A} 2 \mathrm{~B}$, and $\mathrm{A} 3$ on freshly isolated peritoneal macrophages [14]. Both pro- and antiinflammatory BMDM differentiation leads to the upregulation of $\mathrm{A} 2 \mathrm{~A}$ and $\mathrm{A} 2 \mathrm{~B}$. These findings are consistent with previous findings in which pro-inflammatory stimuli like TNF $\alpha$ lead to an upregulation of A2A in macrophages [9]. For the high-sensitivity 
Fig. 5 Calcium flux assay in M1 and M2 macrophages upon ADP stimulation. BMDMs stimulated for $5 \mathrm{~h}$ with $10 \mathrm{ng} / \mathrm{ml} \mathrm{IFN} \gamma+100$ $\mathrm{ng} / \mathrm{ml}$ LPS are described as M1 (red dots) and BMDMs simulated for $5 \mathrm{~h}$ with $20 \mathrm{ng} / \mathrm{ml} \mathrm{IL-4}$ are described as M2 macrophages (green dots). Representative pictures of M1 and M2 macrophages loaded with fluo-4 AM a prior and $\mathbf{b}$ after $200 \mathrm{mM}$ ADP stimulation. c Quantification of fluo-4 AM fluorescence intensity over time upon $200 \mathrm{mM}$ ADP stimulation in M1 (red dots) and M2 (green dots) macrophages

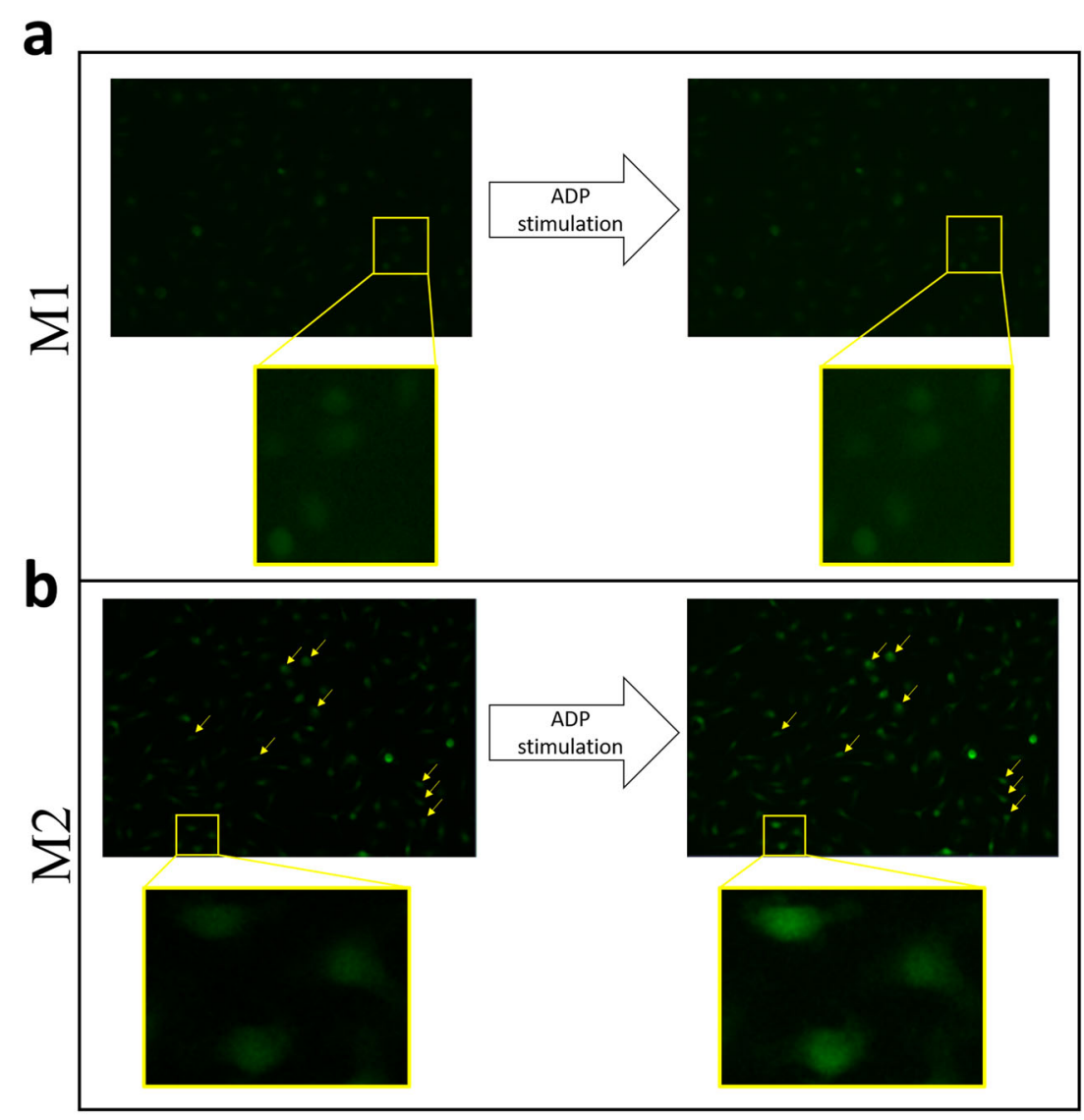

c

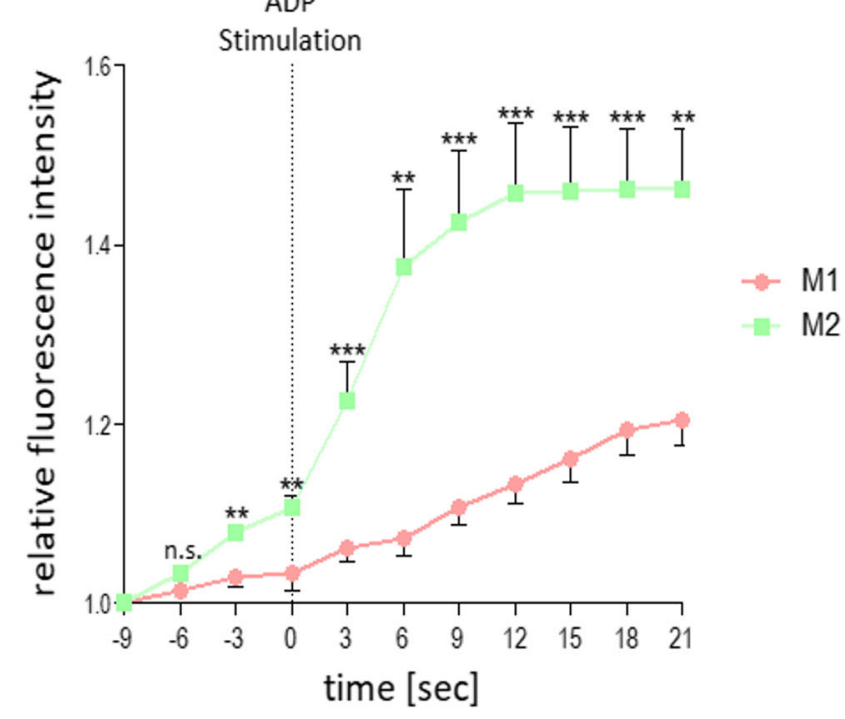

receptor $\mathrm{A} 2 \mathrm{~A}$, this effect was more pronounced in proinflammatory differentiated M1 compared to anti-inflammatory differentiated M2 macrophages (Fig. 2b). There is an evidence that the anti-inflammatory capacity of A2A exceeds the capacity of A2B $[10,11]$ and that the anti-inflammatory effect of adenosine is mainly driven by A2A activation [12]. Previous studies already described a pivotal role of $\mathrm{A} 2 \mathrm{~A}$ in dampening the inflammatory capacity of macrophages [13]. Due to this, the observed increased expression of A2A in M1 macrophages could represent a negative feedback loop by an increased susceptibility to adenosine-dependent anti-inflammatory stimuli. The ectonucleotidases CD39 and CD73 degrade extracellular adenine-nucleotides to adenosine and thereby convert P2 signals to anti-inflammatory P1 signaling. Previous studies already 
described the expression of these ectonucleotidases in freshly isolated macrophages [15]. In this study, we highlighted that compared to M1 macrophages, anti-inflammatory M2 macrophages express higher levels of these ectonucleotidases. By assuming a functional correlation of this expression data, M2 macrophages are more effective in anti-inflammatory P2 to P1 conversion compared to pro-inflammatory M1 macrophages.

Macrophages express a unique repertoire of ATPdependent ionotropic P2X receptors. Freshly isolated murine macrophages [15] as well as human monocytes [16] express $\mathrm{P} 2 \mathrm{X}_{1}, \mathrm{P} 2 \mathrm{X}_{4}$, as well as $\mathrm{P} 2 \mathrm{X}_{7}$. Other investigators observed additional $\mathrm{P} 2 \mathrm{X}_{5}$ expression in macrophages derived from peripheral blood monocytes [17] and alveolar macrophages [18]. These observations are in agreement with our current findings of $\mathrm{P}_{2} \mathrm{X}_{4}$ and $\mathrm{P} 2 \mathrm{X}_{7}$ expression in unstimulated BMDMs (Fig. $1 C)$. The expression of the ionotropic $\mathrm{P} 2 \mathrm{X}_{1}$ receptor was very low compared to $\mathrm{P} 2 \mathrm{X}_{4}$ and $\mathrm{P} 2 \mathrm{X}_{7}$ and therefore designated as below threshold in this study. Our study demonstrated for the first time a dramatic downregulation of both $\mathrm{P}_{2} \mathrm{X}_{4}$ and $\mathrm{P} 2 \mathrm{X}_{7}$ upon pro-inflammatory stimulation to $\mathrm{M} 1$ macrophages. Flow cytometric analysis revealed a $\mathrm{P} 2 \mathrm{X}_{7}$ positive as well as negative population in BMDMs. Intriguingly, only M1differentiated macrophages experience a decrease of the P2 $\mathrm{X}_{7}$-positive population over time (Fig. 3c-f). The downregulation of $\mathrm{P}_{2} \mathrm{X}_{7}$ as well as the reduction of the $\mathrm{P} 2 \mathrm{X}_{7}$ positive population was accompanied by a missing ATP-dependent inflammasome activation, which mimics previous studies where missing P2 $\mathrm{X}_{7}$ signaling completely blocked ATPdependent inflammasome activation in BMDMs [6]. Activation of the $\mathrm{P} 2 \mathrm{X}_{4}$ receptor regulates $\mathrm{P} 2 \mathrm{X}_{7}$ open probability but its deficiency failed to block inflammasome activation [19]. The downregulation of $\mathrm{P} 2 \mathrm{X}_{7}$ could represent another anti-inflammatory negative feedback loop comparable to the upregulation of A2A in inflammatory M1 macrophages. This effect could counteract excessive inflammasome activation and probably protects the body from overwhelming proinflammatory stimuli. In consequence, only noninflammatory primed macrophages would be capable of appropriate inflammasome activation. However, a prolonged exposure to a pro-inflammatory environment reduces macrophages ATP-dependent inflammasome-activating abilities. Another possible reason for the downregulation of the $\mathrm{P}_{2} \mathrm{X}_{7}$ receptor could be a mechanism to preserve the viability of immune cells. Activation of the ionotropic $\mathrm{P} 2 \mathrm{X}_{7}$ leads to a strong ion-flux and thereby promotes cell death. The downregulation of the death receptor $\mathrm{P} 2 \mathrm{X}_{7}$ could prevent cell death and thereby prolong the activity of macrophages in a proinflammatory environment. Furthermore, we observed a strong up-regulation of the $\mathrm{P}_{2} \mathrm{X}_{5}$ in both pro- and antiinflammatory differentiated macrophages (Fig. 3a). Unfortunately, the detailed function of this receptor on macrophages is mainly unknown but recent investigations point at a potential involvement of this receptor in inflammasome activation [20]. We postulate that immunity against Listeria monocytogenes depends on $\mathrm{P}_{2} \mathrm{X}_{5}$-dependent inflammasome activation. Intriguingly, killing of $L$. monocytogenes was independent of the $\mathrm{P}_{2} \mathrm{X}_{5}$ ligand ATP, pointing at an alternative currently unknown activation mechanism of the $\mathrm{P}_{2} \mathrm{X}_{5^{-}}$ inflammasome axis. The fact that in our study both $\mathrm{M} 1$ and M2 macrophages upregulate $\mathrm{P}_{2} \mathrm{X}_{5}$ could make them accessible for this ATP-independent alternative inflammasome axis.

Unlike the P1 and P2X, current literature is inconsistent regarding P2Y receptor expression in macrophages. Our investigations revealed the expression of the $\mathrm{G} \alpha \mathrm{q}$-coupled

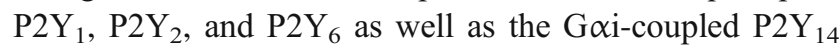
receptor (Fig. 4). Pro- and anti-inflammatory differentiation of macrophages resulted in a clear $\mathrm{G} \alpha \mathrm{q} / \mathrm{G} \alpha \mathrm{i}$ pattern. Whereas anti-inflammatory M2 macrophages predominantly upregulated G $\alpha \mathrm{q}$-coupled P2Y receptors, pro-inflammatory M1 macrophages not only upregulated $\mathrm{G} \alpha \mathrm{i}$-coupled but also downregulated G $\alpha \mathrm{q}$-coupled P2Y receptors. Intriguingly, M1 and $\mathrm{M} 2$ macrophages revealed completely contrasting ADPdependent purinergic receptors $\mathrm{P}_{2} \mathrm{Y}_{1}$ and $\mathrm{P}_{2} \mathrm{Y}_{13}$. We detected $\mathrm{P}_{2} \mathrm{Y}_{1}$ as the predominantly expressed ADP-receptor on M2 macrophages, whereas M1 macrophages exclusively express the ADP receptor $\mathrm{P}_{2} \mathrm{Y}_{13}$. Additionally, the ADP receptor $\mathrm{P}_{2} \mathrm{Y}_{1}$ served as a strong marker to distinguish $\mathrm{P}_{2} \mathrm{Y}_{1}$-negative M1 from $\mathrm{P}_{2} \mathrm{Y}_{1}$-positive $\mathrm{M} 2$ macrophages via flow cytometric analysis (Fig. 4c-g). This contrasting effect suggests further investigations evaluating $\mathrm{P}_{2} \mathrm{Y}_{1}$ and $\mathrm{P}_{2} \mathrm{Y}_{13}$ as potential novel markers in order to distinguish between different macrophages subtypes in vitro and in vivo.

The current study highlights for the first time a complete analysis of the flexible nature of the purinergic receptor profile in different macrophage subtypes like M1 and M2. The unique expression profile explains the silencing of ATP-dependent inflammasome activation in M1 macrophages and the ADPdependent calcium influx in M2 macrophages. Of note, the dichotomous classification of M1 and M2 is a simplification, and macrophage polarization is rather a complex spectrum between different polarization states [2]. Nevertheless, there is strong evidence that macrophages shift between a proinflammatory and anti-inflammatory state, and IFN $\gamma$ with LPS and IL-4 are established stimuli to promote such polarizations. The context-dependent polarization upon environmental stimuli also alters the way macrophages interact with and sense their current surrounding. For example, pro-inflammatory M1 macrophages increase toll-like receptor (TLR) signaling [21] via certain TNFR-associated factors (TRAFs) [22] and upregulate genes involved in endocytosis [3]. The anti-inflammatory M2 polarization upregulates genes associated with lipoprotein uptake [23], fatty acid catabolism [24], and tissue repair [3].

Our study shows that macrophage polarization is accompanied with a unique purinergic receptor profile which renders their behavior towards extracellular nucleotides. This study highlights for the first time the potential of purinergic receptors like $\mathrm{P} 2 \mathrm{X}_{7}$ 
and $\mathrm{P}_{2} \mathrm{Y}_{1}$ as novel macrophage polarization markers and thereby provides new insights into the role of purinergic receptors to shape the complex function of different macrophage subunits. Future studies will evaluate if the targeting of specific macrophage subsets by interfering with their unique purinergic receptor profile has an impact on inflammatory diseases.

Funding Open Access funding enabled and organized by Projekt DEAL. The study was funded by internal funding of the University Heart Center Freiburg, the DFG 1446-2, as well as through the "Stiftung zur Erforschung der Zivilisationserkrankungen." Additionally, this work was supported by the Deutsche Forschungsgemeinschaft (DFG, German Research Foundation) through SFB 1160 (project C02), SFB/ TRR 167 (project A08), SFB 1425 (project P10), GRK 2606 (to O.G.), and under the Germany's Excellence Strategy (CIBSS - EXC-2189 Project ID 390939984, to O.G.).

\section{Declarations}

Ethical approval All mice used for cell isolation were bred and housed under specific pathogen-free conditions at the animal facility of the University of Freiburg. The Animal Care Committee of the University of Freiburg approved all procedures (Reg. No. X18/04R).

Informed consent Not applicable

Consent for publication All authors gave their consent for publication.

Conflicts of interest All authors declare no competing interests.

Open Access This article is licensed under a Creative Commons Attribution 4.0 International License, which permits use, sharing, adaptation, distribution and reproduction in any medium or format, as long as you give appropriate credit to the original author(s) and the source, provide a link to the Creative Commons licence, and indicate if changes were made. The images or other third party material in this article are included in the article's Creative Commons licence, unless indicated otherwise in a credit line to the material. If material is not included in the article's Creative Commons licence and your intended use is not permitted by statutory regulation or exceeds the permitted use, you will need to obtain permission directly from the copyright holder. To view a copy of this licence, visit http://creativecommons.org/licenses/by/4.0/.

\section{References}

1. Wynn TA, Chawla A, Pollard JW (2013) Origins and hallmarks of macrophages: development, homeostasis, and disease. Nature 496(7446):445-455. https://doi.org/10.1038/nature12034

2. P. J. Murray, "Macrophage Polarization,” Annu. Rev. Physiol., vol. 79, pp. 541-566, 10 2017, 10.1146/annurev-physiol-022516034339 .

3. Orecchioni M, Ghosheh Y, Pramod AB, Ley K (2019) Macrophage polarization: different gene signatures in M1(LPS+) vs. classically and M2(LPS-) vs. alternatively activated macrophages. Front Immunol 10:1084. https://doi.org/10.3389/fimmu.2019.01084

4. Kopp R, Krautloher A, Ramírez-Fernández A, Nicke A (2019) P2X7 Interactions and signaling - making head or tail of it. Front Mol Neurosci 12. https://doi.org/10.3389/fnmol.2019.00183
5. Chen Y, Corriden R, Inoue Y, Yip L, Hashiguchi N, Zinkernagel A, Nizet V, Insel PA, Junger WG (Dec. 2006) ATP release guides neutrophil chemotaxis via P2Y2 and A3 receptors. Science 314(5806):1792-1795. https://doi.org/10.1126/science.1132559

6. Stachon P, Heidenreich A, Merz J, Hilgendorf I, Wolf D, Willecke F, von Garlen S, Albrecht P, Härdtner C, Ehrat N, Hoppe N, Reinöhl J, von zur Mühlen C, Bode C, Idzko M, Zirlik A (2017) P2X7 deficiency blocks lesional inflammasome activity and ameliorates atherosclerosis in mice. Circulation 135(25):2524-2533. https://doi.org/10.1161/CIRCULATIONAHA.117.027400

7. Schneider KS, Thomas CJ, Groß O (2013) Inflammasome activation and inhibition in primary murine bone marrow-derived cells, and assays for IL- $1 \alpha$, IL- $1 \beta$, and caspase- 1 . Methods Mol Biol 1040:117-135. https://doi.org/10.1007/978-1-62703-523-1_10

8. Eltzschig HK, Sitkovsky MV, Robson SC (2012) Purinergic Signaling during Inflammation. N Engl J Med 367(24):23222333. https://doi.org/10.1056/NEJMra1205750

9. Khoa ND, Montesinos MC, Reiss AB, Delano D, Awadallah N, Cronstein BN (2001) Inflammatory cytokines regulate function and expression of adenosine $\mathrm{A}(2 \mathrm{~A})$ receptors in human monocytic THP-1 cells. J Immunol 167(7):4026-4032. https://doi.org/10. 4049/jimmunol.167.7.4026

10. Csóka B, Németh ZH, Virág L, Gergely P, Leibovich SJ, Pacher P, Sun CX, Blackburn MR, Vizi ES, Deitch EA, Haskó G (2007) A2A adenosine receptors and $\mathrm{C} / \mathrm{EBPbeta}$ are crucially required for IL-10 production by macrophages exposed to Escherichia coli. Blood 110(7):2685-2695. https://doi.org/10.1182/blood-2007-01-065870

11. Ryzhov S, Zaynagetdinov R, Goldstein AE, Novitskiy SV, Blackburn MR, Biaggioni I, Feoktistov I (2008) Effect of A2B adenosine receptor gene ablation on adenosine-dependent regulation of proinflammatory cytokines. J Pharmacol Exp Ther 324(2): 694-700. https://doi.org/10.1124/jpet.107.131540

12. Haskó G, Pacher P (2008) A2A receptors in inflammation and injury: lessons learned from transgenic animals. J Leukoc Biol 83(3):447-455. https://doi.org/10.1189/jlb.0607359

13. Cekic C, Day Y-J, Sag D, Linden J (2014) Myeloid expression of adenosine $\mathrm{A} 2 \mathrm{~A}$ receptor suppresses $\mathrm{T}$ and $\mathrm{NK}$ cell responses in the solid tumor microenvironment. Cancer Res 74(24):7250-7259. https://doi.org/10.1158/0008-5472.CAN-13-3583

14. del Rey A, Renigunta V, Dalpke AH, Leipziger J, Matos JE, Robaye B, Zuzarte M, Kavelaars A, Hanley PJ (2006) Knock-out mice reveal the contributions of $\mathrm{P} 2 \mathrm{Y}$ and $\mathrm{P} 2 \mathrm{X}$ receptors to nucleotide-induced $\mathrm{Ca}^{2+}$ signaling in macrophages. J Biol Chem 281(46):35147-35155. https://doi.org/10.1074/jbc.M607713200

15. Kronlage $\mathrm{M}$ et al (2010) Autocrine purinergic receptor signaling is essential for macrophage chemotaxis. Sci Signal 3(132):ra55-ra55. https://doi.org/10.1126/scisignal.2000588

16. Wang L, Jacobsen SEW, Bengtsson A, Erlinge D (2004) P2 receptor mRNA expression profiles in human lymphocytes, monocytes and CD34+ stem and progenitor cells. BMC Immunol 5:16. https:// doi.org/10.1186/1471-2172-5-16

17. Akhtari M, Zargar SJ, Vojdanian M, Ashraf-Ganjouei A, Javinani A, Hamzeh E, Rezaiemanesh A, Jamshidi A, Mahmoudi M (2020) $\mathrm{P} 2$ receptors mRNA expression profiles in macrophages from ankylosing spondylitis patients and healthy individuals. Int J Rheum Dis 23(3):350-357. https://doi.org/10.1111/1756-185X.13783

18. Myrtek D, Müller T, Geyer V, Derr N, Ferrari D, Zissel G, Dürk T, Sorichter S, Luttmann W, Kuepper M, Norgauer J, di Virgilio F, Virchow JC Jr, Idzko M (2008) Activation of human alveolar macrophages via $\mathrm{P} 2$ receptors: coupling to intracellular $\mathrm{Ca} 2+$ increases and cytokine secretion. J Immunol 181(3):2181-2188

19. Pérez-Flores G, Lévesque SA, Pacheco J, Vaca L, Lacroix S, PérezCornejo P, Arreola J (2015) The P2X7/P2X4 interaction shapes the purinergic response in murine macrophages. Biochem Biophys Res Commun 467(3):484-490. https://doi.org/10.1016/j.bbrc.2015.10. 025 
20. Jeong YH, Walsh MC, Yu J, Shen H, Wherry EJ, Choi Y (2020) Mice lacking the purinergic receptor P2X5 exhibit defective inflammasome activation and early susceptibility to Listeria monocytogenes. J Immunol. https://doi.org/10.4049/jimmunol. 1901423

21. Laird MHW, Rhee SH, Perkins DJ, Medvedev AE, Piao W, Fenton MJ, Vogel SN (2009) TLR4/MyD88/PI3K interactions regulate TLR4 signaling. J Leukoc Biol 85(6):966-977. https://doi.org/10. $1189 / \mathrm{jlb} .1208763$

22. Jin J, Xiao Y, Hu H, Zou Q, Li Y, Gao Y, Ge W, Cheng X, Sun SC (Jan. 2015) Proinflammatory TLR signalling is regulated by a
TRAF2-dependent proteolysis mechanism in macrophages. Nat Commun 6:5930. https://doi.org/10.1038/ncomms6930

23. Chawla A (2010) Control of macrophage activation and function by PPARs. Circ Res 106(10):1559-1569. https://doi.org/10.1161/ CIRCRESAHA.110.216523

24. Nomura M, Liu J, Rovira II, Gonzalez-Hurtado E, Lee J, Wolfgang MJ, Finkel T (2016) Fatty acid oxidation in macrophage polarization. Nat Immunol 17(3):216-217. https://doi.org/10.1038/ni.3366

Publisher's note Springer Nature remains neutral with regard to jurisdictional claims in published maps and institutional affiliations. 